\title{
Manajemen Kurikulum Perspektif Oliva : Telaah Epitemologis
}

\author{
Istianatul Hasanah \\ Universitas Nurul Jadid Paiton Probolinggo \\ istianatulhasanah05@gmail.com
}

\begin{abstract}
Curriculum management is a system of curriculum management that is cooperative, comprehensive, and systematic in order to realize the achievement of curriculum objectives. A good curriculum is a curriculum that follows the development of science and technology based on society. The management of a curriculum determines success and failure in education. Therefore, Management curriculum is Importent thing in a scool education by principle education process which can work running wellby reaching a goal, such is garduate competent standardthat must be domeneted by student and motivated the teacher to alwasy implement the education.
\end{abstract}

Keywords: Curriculum Management, Curriculum

\begin{abstract}
Abstrak : Kurikulum menejemen merupakan sistem kurikulum manajemen yg koopratif, komperensif dan sistematis supaya menyadarkan prestasi dari kurikulum objektif. Kurikulum yang bagus itu adalah kurikulum yang mengikuti perkembangan IPTEK yang sesuai dengan masyarkat. Manajemen kurikulum menentukan sukses dan kegagalan sebuah pendidikan. oleh karena itu manajemen kurikulum merupakan hal pokok di dalam satuan pendidikan sekolah dengan prinsip proses pembelajaran akan berjalan dengan efektif, dengan pencapaian tujuan sebagai tolak. ukurnya, dan juga berupa standar kompetensi lulusan yang harus dikuasai oleh siswa serta menopang guru untuk secara terus menerus melaksanakan menyempurnakan pembelajarannya.
\end{abstract}

Kata Kunci: Manajemen Kurikulum, Kurikulum

\section{Pendahuluan}

Sumber daya manusia sangatlah penting untuk mengukur tingkat kemajuan suatu Negara, sekalipun Negara tersebut memiliki sumber daya alam yang bisa dikatakanmelimpah ruah akan tetapi tidak ditopang ataupun didukung oleh sumber daya manusia yang berkualitas maka negara tersebut tidaklah dikatakan sebuah negara yang maju.

Jadi, untuk meningkatkan sumber daya manusia itu tidak luput dari namanya sebuah kegiatan pendidikan, di mana pendidikan itu merupakan unsur utama untuk menjadikan manusia yang bermutu dan juga inovatif. ${ }^{1}$ Pendidikan juga mengarahkan manusia dari sebelumnya tidak mengetahui banyak hal menjadi tahu banyak, sebelumnya berperilaku kurang baik menjadi berperilaku

1 Zamroni Hasan Baharun, Manajemen Mutu Pendidikan: Ikbtiar Dalam Meningkatkan Mutu Pendidikan Madrasah Melalui Pendekatan Balanced Scorecard (Tulungagung: Akademia Pustaka, 2017). 
baik. Pendidikan juga menjadi sebuah fasilitas yang bisa membuat manusia menjadi dewasa, bertanggungjawab, jujur, beradab, dan berkarakter. ${ }^{2}$

Pendidikan juga sebagai ujung tombak penerus dan merupakan perbaikan kondisi yang ada setiap saat, setiap hari bahkan setiap detiknya manusia itu dituntut untuk meng upgrade pengetahuan sehingga menciptakan keterampilan yang lebih baik. Dalam meningkat kualitas pendidikan itu tidak bisa dikatakan sebuah amanah yang bisa dianggap enteng karena amanah tersebut bukan hanya berhubungan dengan permasalahan teknis saja, akan tetapi cangkupan maslahnya berhubungan dengan persoalan yang sangat pelik dan kompleks baik yang menyangkut sebuah perencanaan, pendanaan, maupun efisiensi dan efektivitas penyelenggaraan. Maka dari itu Apabila ingin melakukan suatu kegiatan harus dilakukan dan dikelola dengan baik, rapi dan teratur mengapa demikian? Karena, apabila melakukan suatu perbuatan yang dilakukan secara asal-asalan tidak akan mendapatkan hasil yang maksimal. Manajemen bisa memilikiarti menata segala suatu apapun agar dilaksanakan dengan baik, tepat, teratur dan tuntas itu semua merupakan hal yang sangat penting karena suatu hal apapun tanpa proses manajemen tidak akan mendapatkan suatu hasil yang baik, sebaliknya sesulit dan sebesar apapun suatu hal yang dilakukan tetapi diproses dengan manajemen yang baik maka bisa dipastikan akan berhasil dengan baik, efektif dan efisien.

Manajemen yang efektif itu membuat yang benar berarti menjadikan sesuatu itu selaras dengan tujuan yang diinginkan dalam organisasi tersebut, sedangkan mengkreasikan alternatif-alternatif adalah bermaksud memberikan suatu pertimbangan yang memadai sebelum bertindak agar efek negatif diterima sedikit mungkin. Sedangkan manajemen efesien itu bisa diperoleh dengan cara:

${ }^{2}$ Dinn Wahyudi, 'MANAJEMEN KURIKULUM DALAM PENDIDIKAN PROFESI GURU (STUDI KASUS DI UNIVERSITAS PENDIDIKAN INDONESIA)', Jurnal Kependidikan, 46.2 (2016), 259-70. 
60 | TADBIR : Jurnal Studi Manajemen Pendidikan, Vol. 3, No. 1, Mei 2019

(1) Mengerjakan segala sesuatu dengan benar (2) Kalau terjadi sebuah permasalahan hendaklah segera diselesaikan denag sebaik-baiknya (3) Mengamankan sumber-sumber pendidikan dengan cara mengoordinasi sumbersumber itu dengan sebaik-baiknya (4) Setiap petugas dan pegawai ataupun seorang guru itu diharuskan mengikuti setiap tugas-tugas dan pekerjaannya (5) Setiap manajer itu hendaklah dapat menekan biaya pendidikan agatr tidak mengorbankan produksi. ${ }^{3}$

Maka dari aktivitas yang baik itu harus selalu ada rencana atau sebuah program yang dibuat sebelumnya, yang dapat digunakan sebagai panduan pelaksanaannya. Dimana program itu dikenal dengan dengan sebutan kurikulum, Kurikulum juga sering menjadi buah bibir oleh berbagai pihak, misalnya,dimana disaat sebagian anggota suatu masyarakat bisa melihat hasil (out-put) dari suatu lembaga pendidikan yang belum mencerminkan apa yang diinginkannya, selalu menuding bahwa sanya kurikulum yang ada pada lembaga tersebut tidaklah baik. Ketika para orang tua akan memasukkan putra putrinya ke suatu instansi, pastinya yang mereka lakukan terlebih dahulu yaitu mempertimbangkan reputasi apa saja yang telah diraih oleh instansi tersebut dalam menerapkan kurikulum pada proses pembelajarannya. ${ }^{4}$

\section{Hakikat Manajemen}

Berbicara tentang pendidikan sama dengan membahas hajat hidup orang banyak. Pendidikan disini juga akan merubah presfektif manusia sehingga berujung pada pembentukan perilaku setiap insan. Mungkin inilah alasan kampanye pendidikan sepanjang hayat begitu gencar disuarakan. Proses

26.

${ }^{3}$ Made Pidarta, 'Manajemen Pendidikan Indonesia' (jakarta: PT Renika Cipta, 2011), p.

${ }^{4}$ Khuzaimah, 'Paradigma Pengembangan Kurikulum Pendidikan Agama Islam Di Sekolah (Analisis Berbagai Kritik Terhadap PAI)', Pendidikan, V.1 (2017), 105-18. 
pendidikan akan baik, jika manajemennya juga baik. Para ahli memberikan keterangan tentang pengertian manajemen. ${ }^{5}$

Sedangkan dilihat dari asal katanya manajemen itu berasal dari suatu kata management dimana kata itu merupakan bentuk dari nouns yaitu dari kata kerja to manage yang memiliki pemahaman tentang mengurus, mengatur, melaksanakan, dan mengelola, maka manajemen yaitu pengurusan, pengaturan, pengelolaan dan pelaksaan. ${ }^{6}$ Kata manajemen disini juga berasal dari bahasa parancis kuno, yaitu management dimana kata tersebut memiliki arti seni dalam melaksanakan dan mengatur. Bisa dilihat juga dalam kamus besar bahasa indonesia, manajemen diartikan sebagai pemberdayaan sumber daya secara efektif untuk mencapai sasaran. ${ }^{7}$

Jadi bisa ditarik kesimpulan manajemen secara etimologi yaitu pelaksanaan sebuah kegiatan yang dimana kegiatan tersebut bertujuan untuk mengelola sumber daya yang ada untuk mencapai subuah tujuan secara efektif dan efisien.

Pengertian di atas manajemen secara etimologi selanjutnya pengertian manajemen secara terminologi menurut berbagai tokoh diantaranya: Pertama, Dessler, management process is some of the specific activities involved in each function include: planning, organizing stafing, leading and controling. Kedua, Herny, mendifinisikan manajemen sebagai proses pendayagunaan bahan baku dan sumber daya manusia, untuk mencapai tujan yang ditetapkan, dimana proses tersebut pasti melibatkan organisasi, arahan, koordinasi, dan evaluasi orang-orang guna mencapai tujuan. Kedua, Sudjana, menurutnya manajemen sebagai kegiatan yang

${ }^{5}$ Kaimuddin, 'Implementasi Pendidikan Karakter Dalam Kurikulum 2013', Dinamika Ilmu, 14.1 (2014), 47-64 < https://doi.org/10.1061/(ASCE)0733-9410(1991)117>.

6 Ayon Triyono, 'Pradigma Baru Manajemen Sumber Daya Manusia' (jakarta: Oryza, 2012), p. 12.

7 Najib, 'Manajemen Masjid Sekolah Sebagai Laboratorium Pendidikan Karakter Konsep Dan Implementasinya' (Yogyakarta: Cava Media, 2015), p. 5. 
diselenggaraka oleh seseorang atau lebih, dalam sebuah organisasi maupun lembaga guna mencapai suatu tujuan yang telah ditetapkan. ${ }^{8}$

Dari pembahsan tiga tokoh di atas manajemen secara terminologi bisa diartikan sebuah pengontrolan aktivitas yang dilakukan seseorang maupun organisasi dengan melibatkan suatu proses evaluasi dalam mencapai suatu tujuan yang telah ditetapkan.

Hadari Nawawi juga mengartikan manajemen merupakan sebuah kegiatan yang dilakukan oleh seorang manajer dalam memanage sebuah organisasi, lembaga, ataupun sebuah perusahaan. Menurut Muhammad Azhari yang mengutip dari ramayulis juga menyatakan bahwa pengertian yang sama dengan hakikat manajemen yaitual-tadbir (pengaturan). ${ }^{9}$ Dimana manajemenen disini merupakan derivasi dari kata dabbara (mengatur) yang banyak terdapat dalam Al Qur'an seperti frman Allah SWT:

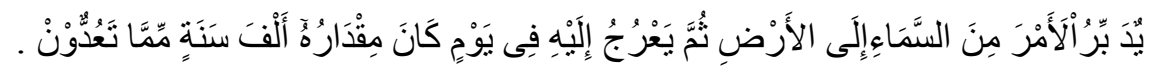

Artinya: Dia mengatur urusan dari langit ke bumi, kemudian (urusan) itu naik kepadanya dalam satu bari yang kadarnya adalab seribu tahun menurut perbitunganmu (Q.S. As-Sajdab : 5)

Berikut manajemen yang efektif itu mempunyai dua tujuan utama diantaranya: (a) Membantu siswa untuk menghabiskan banyak waktu dalam belajar dan mengarahkan kegiatan yang sekiranya tidak sesuai dengan tujuan pembelajaran (b) Mencegah siswa mengembangkan masalah akademik dan emosional siswa. ${ }^{10}$

8 Agus wibowo, 'Manajemen Pendidikan Karakter Di Sekolah Konsep Dan Praktik Implementasi' (yogyakarta: pustaka Pelajar, 2013), pp. 30-31.

${ }^{9}$ Muhammad Azhari, 'PENINGKATAN MUTU PENDIDIKAN ( Studi Kasus Pondok Pesantren Ulumul Qur' an Stabat )', 124-35.

${ }^{10}$ Mutmainnah Abdul HAmid Wahid, Chusnul Mualli, 'Manajemen Kelas Dalam Menciptakan Suasana Belajar Yang Kondusif; Upaya Peningkatan Prestasi Belajar Siswa', AlFikrah, V.2 (2012). 
Sedangkan ilmu manajemen sangat bermanfaat untuk mengatur segala aktivitas kehidupan manusia. Setiap manusia dari dulu sampai sekarang mempunyaikesibukan yang beragam dan selalu berubah seiring perkembangan zaman.Penerapan fungsi manajemen pun harus disesuaikan dengan aktivitasmanusia di setiap tempat dan waktu yang berbeda. Sudjana mengutippendapat Henry Fayol saat menjabarkan fungsi manajemen yaitu planning(perencanaan), organizing (pengorganisasian), commanding (perintah),coordinating(pengkoordinasian), controlling (pengawasan). Dimana rangkaian fungsi di atasterkenal dengan singkatan POCCC. Agak sedikit berbeda, Patrick E. Conner menggolongkan fungsi manajemen dalam empat urutan yaituplanning (perencanaan),organizing (pengorganisasian), staffing (penempatanstaf), dan controlling(pengawasan). Pendapat lainnya Suharsimi Arikuntomenjabarkan fungsi yang menjadi pokok kegiatan manajemen terdiri dariperencanaan, pengorganisasian, pengarahan, pengkoordinasiaan, pengkomunikasian, evaluasi. ${ }^{11}$

Maka daripemaparan berbagai pakar dapat disimpulkan secara pokok bahwa fungsi manajemen itu tidak akan terlepas dari sebuah aktivitas perencanaan, pelaksanaan, dan sebuah evaluasi. Untuk mempengaruhi sebuah kesuksesan perencanaan, pelaksanaan dan evaluasi itu tergantung kualitas pemimpinnya dan kualitas sumberdaya manusia.

\section{Kurikulum Perspektif Oliva}

Salah satu komponen terpenting dalam sebuah pendidikan yang sering diabaikan itu adalah kurikulum. Dimana kurikulum itu memiliki posisi yang begitu strategis karena secara umum kurikulum adalah sebuah gambaran dari sebuah visi, misi, dan tujuan dari pendidikan yang dianut oleh bangsa tersebut.

${ }^{11}$ Vivit Nur, Arista Putra, and Universitas Gadjah Mada, 'Manajemen Perencanaan Pembelajaran Untuk Kaderisasi Muballigh Di Pondok Pesantren Takwinul Muballighin Yogyakarta', 3 (2018). 
Hal ini juga sekaligus memposisikan kurikulum itu sebagai sentral muatanmuatan nilai yang akan ditransformasikan kepada peserta didik. ${ }^{12}$

Kata kurikulum berasal dari bahasa Yunani dimana kata kurikulum itu di digunakan dalam suatu bidang olahraga yaitucurrereyangmemiliki arti jarak yang ditempuhseorang pelari, yaitu dimana suatu jarak yang diharuskan dilewati dalam kegiatan berlari mulai dari garis start hingga finish. Pengertian ini kemudian dapat diterapkan di dalam bidang pendidikan. ${ }^{13}$

Omar Mohammad Al-TaoumyAl-Syaibany dengan merujuk pada kamus bahasa Arab didapati kata-kata Manhaj' (Kurikulum) memiliki arti jalan yang terang, atau jalan terang yang akan ditempuh oleh manusia dalam berbagai aspek kehidupan, kemudian kata manhaj ditarik dalam pendidikan, maka kata 'Manhaj' (kurikulum) diartikan sebagai jalan terang yang pasti dilalui oleh seorang pendidik maupun guru dengan peserta didik ataupun yang dilatihnya untuk mengembangkan suatu pengetahuan, keterampilan dan sikap mereka. Kurikulum dijadikan sebuah rancangan dan suatu pengalaman yang didapat dari belajar dan juga suatu hasil belajar yang diharapkan, diformulasikan melalui sebuah ilmu pengetahuan dan suatu kegiatan yang sudah tersusun secara teratur, dan akan diberikan kepada peserta didik di yang berada dibawah tanggung jawab sekolah dalam membantu suatu pertumbuhan pribadi peserta didik dalam kompetensi sosialnya. ${ }^{14}$

Maka dari pembahasan di atas dapat digambarkan bahwasanya kurikulum terakhir itu sangat identik dengan suatu proses pembelajaran, ${ }^{15}$ maka atas pemahaman tersebut istilah kurikulum itu diterapkan dalam pendidikan. Dalam

\footnotetext{
12Sugeng Kurniawan, 'KONSEP MANAJEMEN PENDIDIKAN ISLAM PERSPEKTIF AL-QUR ' AN DAN AL-HADITS', Nur El-Islam, 2.2 (2006), 1-34.

${ }^{13}$ Syamsul Bahri, 'Pengembangan Kurikulum Dasar Dan Tujuannya', Jurnal Ilmiah Islam Futura, 11.1 (2014), 15 <https://doi.org/10.22373/jiif.v11i1.61>.

${ }^{14}$ Khuzaimah.

${ }^{15}$ Syafiqiyah Adhimiy Hasan Baharun, 'Curriculum Development Throught Creatibe Lesson Plan', Cendikia, 16.1 (2018), 41-62.
} 
konteks pendidikan Islam kurikulum itu bisa dikaji sebagai suatu perangkat rencana, tujuan, isi dan bahan ajar serta cara yang dipakai oleh seorang pendidik yang bertujuan untuk membimbing peserta didiknya kearah tujuan tertinggi pendidikan Islam, melalui pengumpulan beberapa pengetahuan, keterampilan dan sikap. ${ }^{16}$

Setelah pemaparan secara etimologi di atas maka kurikulum dalam arti termiologi dapat dipahami sebaimana berikut: (1) Tradisional atau sempit. Tradisional mengatakan bahwa awalnya kurikulum itu dipahami sebagai suatu subject atau dipahami sebagai suatu mata pelajaran maupun suatu bidang studi yang mana peserta didik harus memahaminya secara kognitif guna mendapatkan ijazah. Sejumlah mata pelajaran atau training yang disodorkan sebagai suatu produk atau pendidikan. Adapun Taba mengemukakan kurikulum itu sebagai suatu rencana dalam belajar. Sehingga istilah kurikulum pada sekarang ini dianggap sama dengan pedoman mengajar, silabus atau buku teks yang ditetapkan course. (2) Modern atau luas. Sedangkan dalam istilah modern menyebutkan kurikulum merupakan sebuah pengalaman peserta didik yang diperoleh baik ketika dalam suatu proses pembelajaran ${ }^{17}$ di dalam kelas yang mana pastinya proses tersebut terjadwal maupun pengalaman yang dihasilkan dari proses pembelajarannya di luar kelas (seperti laboratorium, halamanataupun kegiatan ektrakulikuler)bahkan kegiatan diluar sekolah (seperti kunjungan wisata, musium) yang pastinya mempunyai tujuandan berada di bawah tanggung jawab sekolah. $^{18}$

\footnotetext{
${ }^{16}$ Didiyanto, 'PARADIGMA PENGEMBANGAN KURIKULUM PAI DI Abstrak', Edureligia, 1.2 (2017).

${ }^{17}$ Ahmad Fauzi and others, 'E-Learning in Pesantren : Learning Transformation Based on the Value of Pesantren', Journal of Physics: Conf. Series 1114, 1114 (2018), 1-6 <https://doi.org/10.1088/1742-6596/1114/1/012062>.

${ }^{18}$ Wiji Hidayati, 'Manajemen Kurikulum Pendidikan Agama Islam Dan Budi Pekerti Jenjang SMA Bermuatan Keilmuan Integrasi Interkoneksi', 1.November (2016), 195-225.
} 
Oliver dalam Oliva juga memberi ketegasan bahwa sanya kurikulum itu harus menjadi alat penyusunan suatu pengetahuan secara sistematis yang dikembangkan dengan kendali manajerial dari institusi pendidikan, ${ }^{19}$

Konsep kurikulum itu berkembang secara pesat dimana perkembangan tersebut searah dengan perkembangan teori maupun praktik pendidikan yang juga memilik sebuah variasi yangsesuai dengan aliran maupun teori pendidikan yang dianutnya. Berikut hal yang harus mendapatkan suatu penjelasan dalam teori kurikulum adalah sebuah konsep kurikulum. Dimana terdapat tiga konsep tentang kurikulum, yaitu kurikulum itu sebagai substansi, sebagai sistem, danjuga kurikulum sebagai bidang studi.

Konsep pertama, kurikulum sebagai suatu substansi. Kurikulum bisa diartikan dengan sebuah rencana dalam kegiatan belajar bagi peserta didik di sekolah, ataupun diartikan sebagai perangkat tujuan yang ingin dicapai. Kurikulum disini juga dapat menunjuk kepada suatu dokumen yang mengandung tentang rumusan suatu tujuan, bahan ajar, kegiatan belajarmengajar, jadwal, dan evaluasi. Kurikulum juga bisa dianggap sebagai suatu dokumen yang merupakan hasil keputusan bersama baik antara pemegang keputusan dan penyusun kurikulum pendidikan dengan masyarakat. Dimana lingkup cangkupan kurikulumnya itu tertentu bisa cangkupannya sebatas sekolah, kabupaten, profinsi maupun seluruh Negara saja.

Konsep kedua, adalah kurikulum sebagai suatu sistem, dimana Sistem yang digunakan dalam kurikulum adalah suatu bagian dari sebuah sistem persekolahan, sistem pendidikan, bahkan sistem kemasyarakatan. Suatu sistem kurikulum itu bisanya mencakup struktur personalia, dan tahapan kerja serta bagaimana cara menyusun suatu kurikulum, melaksanakannya, mengevaluasi, dan menyempurnakannya. Dan hasil dari suatu sistem kurikulum yaitu 
tersusunnya suatu kurikulum, dan fungsi dari sistem kurikulum adalah bagaimana memelihara kurikulum agar tetap dinamis. Konsep ketiga, Kurikulum bisa dikatan sebagai bidang studi kurikulum dimana hal ini sebagai pokok kajian para pakar kurikulum juga pakar pendidikan maupun pengajaran. Kurikulum sebagai bidang studi memiliki tujuan untuk memperluas tentang keilmuan yang berkaitan dengan kurikulum dan juga sitm dari kurikulum tersebut. Dimana orang yang mengkaji lebih jauh tentang bidang kurikulum itu juga bergelut dengan konsep awal tentang kurikulum itu sendidri. Melalui berbagai observasi dan juga melakukan studi kepustakaan dalam mendapatkan pengetahuan yang lebih akurat juga dibutuhkan suatu penelitian dan percobaan guna untuk mengumpulkan pengetahuan lebih lanjut dan juga untuk memperkaya serta memperkuat tentang teori tentang bidang studi kurikulum. ${ }^{20}$

Kurikulum merupakan Kurikulum merupakan suatu inovasi yang telah lama di cita-citakan dalam dunia pendidikan. Dimana apa yang sudah dirancang dalam kurikulum formal pada hakikatnya mencerminkan tentang apa yang telah dicita-citakan dalam wujud suatu hasil dari pendidikan yang ingin diperoleh. Dalam pengimplementasian suatu kurikulum para perumus dari kurikulum itu haruslah bisa memahami berbagai macam prilaku yang akan timbul dari hasil kurikulum. Hal ini dimaksudkan agar bentuk-bentuk perilaku tersebut bisa di munculkan secara sigifikan memlalui berbagai upaya yang disengaja bahkan dengan melalui suatu pengembangan yang sudah terencana. ${ }^{21}$

Menurut Hasan Baharun yang mengutip dari Zakiah Drajat memaparkan bahwa, tujuan dari kurikulum yang terkandung dalam suatu instansi itu terdiri dari dua tujuan pokok diantaranya: (a) Dari keseluruhan tujuan yang ingin dicapai oleh instansi itu terdapat suatu komponen yang berhubungan dengan

\footnotetext{
${ }^{20}$ Nur Ahid, 'Konsep Dan Teori Kurikulum Dalam Dunia Pendidikan', Islamica, 1.1 (2006), 12-29.

${ }^{21}$ Meike D Mamentu and M Si, 'Manajemen Pendidikan Dan Pengajar Pada Sma Negeri Remboken Kabupaten Minahasa', 3.5 (2013), 58-66.
} 
suatu arah maupun suatu hasil yang diinginkan. Dalam lingkip luas tujuan dari kurikulum itu berkaitan erat dengan filsafat maupun sistem nilai yang diadopsi oleh suatu bangsa. Dimana rumusan dari tujuan yang diinginkan tersebuut mengambarkan hal yang dicita-citakan oleh masyarakat. (b) tujuan yang ingin diperoleh dari setiap bidang studi. Tujuan-tujuan dari setiap bidang studi dalam kurikulum itu ada yang mengatakan tujuan tersebut berkaitan dengan kurikulum itu sendiri dan juga ada yang mengatakan bahwa tujuan itu disebut dengan tujuan intruksional yang mana tujuan intruksional itu merupakan suatu proses lanjutan dari kurikuler. ${ }^{22}$

Sedangkan inti kajian dari kurikulum itu sendiri ada 4 yaitu: (1) Tujuan pendidikan yang sepertia apa yang akan dicapai oleh instansi tersebut? (2) Pengalaman yang seperti apa yang harus didapatkan guna memdapatkan tujuan pendidikan tersebut? (3) Bagaimana caranya agar bisa mengatur suatau pengalaman yang didapat bisa menjadi efektif dalam pendidikan. (4) Bagaimana caranya agar tujuan yang telah ditetapkan itu bisa tercapai. ${ }^{23}$

\section{Manajemen Kurikulum Perspektif Oliva}

Manajemen kurikulum merupakan salah satu bagian dari manajemen pendidikan. Rusman berpendapat bahwa manajemen kurikulum itu sebagai suatu sistem pengelolaan kurikulum yang kooperatif, komprehensif, sistemik dan sistematik dalam rangka mewujudkan ketercapaian tujuan kurikulum. Manajemen kurikulum merupakan hal pokok di dalam satuan pendidikan sekolah dengan prinsip proses pembelajaran dapat berjalan dengan baik, dengan tolok ukur pencapaian tujuan, berupa standar kompetensi lulusan yang harus dikuasai siswa dan mendorong guru untuk secara terus menerus melaksanakan menyempurnakan pembelajarannya. ${ }^{24}$

\footnotetext{
${ }^{22}$ Hasan Baharun, Pengembangan Kurikulum : TEORI DAN PRAKTIK, 2017.

${ }^{23}$ Ahid.

${ }^{24}$ Hidayati.
} 
Adapun ruang lingkup pembahasan manajemen kurikulum sebagaimana teori manajemen yang umum, disebut dengan fungsi manajemen. Fungsi manajemen kurikulum itu sendiri dibagi ke dalam tiga ruang lingkup yaitu: pertama perencanaan kurikulum, kedua pelaksanaan kurikulum dan ketiga evaluasi kurikulum. Adapun rinciannya dijelaskan di bawah ini: Pertama Perencanaan Kurikulum, Menurut Beane dalam Hamalik, suatu perencanaan kurikulum itu merupakan serangkaian tidakan ketika peserta didik membuat keputusan tentang bagai mana tujuan pembelajaran itu akan diperoleh, ${ }^{25}$ sedangkan cara memperoleh tujuan itu yaitu dengan melalui serangkaian kegiatan belajar mengajar, dengan menela`ah keefektifan beserta kemamfaatan metode yang digunakan.

Dalam perencanaan kurikulum ini, ada proses perencanaan kurikulum yang meliputi beberapa kegiatan yang harus diperhatikan. Uraian sistematis dipaparkan oleh Rusman, yaitu: (a) perumusan tujuan kurikulum, (b) landasan perencanaan kurikulum, (c) perumusan isi kurikulum dan (d) organisasi kurikulum.Yang Kedua Pelaksanaan Kurikulum Menurut Wahyuddin, pelaksanaan atau implementasi kurikulum adalah penerapan atau pelaksanaan program kurikulum yang telah dikembangkan dalam tahap sebelumnya,kemudian dujicobakan dengan pelaksanaan dan pengelolaan yang disesuaikan terhadapsituasi dan kondisi lapangan dan karakteristik peserta didik baik perkembangan intelektual, emosional dan juga fisik. Jenis pelaksanaan kurikulum meliputi: (a) Pelaksanaan kurikulum tingkat sekolah dan pelaksanaaan kurikulum tingkat kelas. Kemudian tahapan pelaksanaan kurikulum meliputi: pengembangan program, pelaksanaan pembelajaran, dan evaluasi proses. Sedangkan kegiatan selanjutnya adalah supervisi (pengawasan) pelaksanaan kurikulum. Yang Ketiga Evaluasi Kurikulum Hamid Hasan

25 Muhammad Mushfi and El Iq, 'Implementasi Media Pembelajaran Berbasis Teknologi Informasi Dan Komunikasi Dalam', Tarbiyatuna, 3.1 (2019), 28-38. 
mendefinisikan evaluasi kurikulum adalah usaha sistematis mengumpulkan informasi mengenai suatu kurikulum untuk digunakan sebagai pertimbangan mengenai nilai, dan arti dari kurikulum dalam suatu konteks tertentu. Nasution menjelaskan ada lima model metodologi penilaian dalam evaluasi kurikulum, antara lain: ModelDiskrepansi Provus, Model Kontingensi-Kontingensi Stake, Model CIPPStufflebeam, Model Transformasi Kualitatif Eisner dan Model Lingkaran TertutupCorrigan. ${ }^{26}$

The Oliva Model is the extension from the Saylor, Alexander, Lewis (SAL) and the context,input, process, product (CIPP) Models. The SAL Model was developed by J.Galen Saylor, William M. Alexander and Arthur J. Lewis in 1981 while the CIPP Model wasdeveloped in 1971 by Daniel L. Stufflebeam. Oliva adds eight concepts of curriculumconstruction. Scope, Relevance, Balance, Integration, Sequence, Continuity, Articulation., Transferability.

The Oliva Model consists of twelve components:Statement of aims and philosophy ofeducation, Specification of needs, Curriculum goals, Curriculum objectives, Organization and implementation of the curriculum, Specification of instructional goals, Specification of instructional objectives, Selection of strategies, Preliminary and finalselection of evaluation techniques, Implementation of strategies, Evaluation ofinstruction, and Evaluation of the curriculum. $^{27}$

Lebih lanjut bahwa model pengembangan kurikulum ini bsa digunakan dalam tiga dimensi: (1) Bisa digunakan untuk penyempurnaan kurikulum sekolah dalam bidang-bidang yang dikhususkan seperti mata pelajaran yang telah ditentukan oleh pihak sekolah, baik dalam tataran perencanaan kurikulumnya

\footnotetext{
${ }^{26}$ Muhammad Rouf, 'MANAJEMEN KURIKULUM INTEGRATIF MADRASAH PESANTREN', Al-Hikmah Studi Keisaman, 6.September (2016), 1-21.

${ }^{27}$ Dazmin Daud and Halim Ahmad, 'Oliva Model in Malaysian Logistics Curriculum : A Conceptual Framework Paper’, 2.3 (2012), 217-28 < https://doi.org/10.5296/ijld.v2i3.1884>.
} 
maupun dalam proses pembelajarannya. (2) Bisa digunakan dalam membuat keputusan dan merancang suatu program kurikulum. (3) Bisa digunakan untuk meningkatkan pengembangan suatu program pembelajaran secara lebih khusus. $^{28}$

Model oliva merupaka model pengembangan kurikulum yang masuk dalam kategori deduktif dimana model deduktif iniadalah model yang dimulai dari hal umum ke hal yang khusus.

Terdapat lima prinsip yang harus diperhatikan dalam melaksanakan manajemen kurikulum, yaitu: Pertama, produktivitas dimana hasil yang akan didapatkan dalam suatu kegiatan kurikulum adalah suatu sudut pandang yang harus diperhatikan dalam manajemen kurikulumnya berupa apakah proses belajar mengajar yang dilalui oleh peserta didik itu sejalan dengan tujuan dari kurikulum tersebut. Kedua, Demokrasi, dimana pelaksaan dari kurikulum itu harus berdasarkan asas demokrasi sehingga dalam menempatkan suatu pengelolaan dan pelaksanaan dari subjek didik itu pada tempat seharusnya sehingga subjek didik itu mampu melaksanakan tugas dengan rasa tanggung jawab guna mencapai tujuan dari kurikulum. Ketiga, Kooperatif, untuk memperoleh hasil yang diharapkan dalam kegiatan manajemen kurikulum, perlu adanya kerja sama yang positif dari berbagai pihak yang terlibat, Keempat Efesien dan efektifitas, dimana rangkaian dari kegiatan manajemen kurikulum itu haruslah efektif dan efisien guna mencapai tujuan dari kurikulum itu sendiri, sehingga kegiatan dari manajemen kurikulum itu mampu mendapatkan hasil yang berguna sehingga bisa menghemat biaya, tenaga dan waktu yang singkat. Kelima, mengarahkan visi dan misi beserta tujuan kurikulum yang sudah ditetapkan agar proses manajemen kurikulum yang dilakukan mampu

\footnotetext{
${ }^{28}$ Baharun.
} 
72 | TADBIR : Jurnal Studi Manajemen Pendidikan, Vol. 3, No. 1, Mei 2019

memperkuat besrta mampu mengarahkan visi dan misi,beserta tujuan kurikulum. ${ }^{29}$

\section{Penutup}

Kurikulum itu harus menjadi alat rekonstruksi pengetahuan secara sistematis yang dikembangkan dengan kendali manajerial dari institusi pendidikan. Sedangkan ruang lingkup pembahasan manajemen kurikulum sebagaimana teori manajemen yang umum, disebut dengan fungsi manajemen. Fungsi manajemen kurikulum itu sendiri dibagi ke dalam tiga ruang lingkup yaitu: pertama perencanaan kurikulum, kedua pelaksanaan kurikulum dan ketiga evaluasi kurikulum.

Manajemen kurikulum oliva itu bagaimana pengelolaannya bersifat sederhana dan terdapat 12 komponen yang saling melengkapi dan saling berkaitan untuk mencapai sebuah tujuan yang ingin dicapai. 30.

${ }^{29}$ Ibrahim Nasbi, 'Manajemen Kurikulum':, JURNAL IDAARAH, I.36 (2017), 318- 


\section{Daftar Pustaka}

Abdul Hamid Wahid, Chusnul Mualli, Mutmainnah, 'Manajemen Kelas Dalam Menciptakan Suasana Belajar Yang Kondusif; Upaya Peningkatan Prestasi Belajar Siswa', Al-Fikrah, V (2012)

Agus wibowo, 'Manajemen Pendidikan Karakter Di Sekolah Konsep Dan Praktik Implementasi' (yogyakarta: pustaka Pelajar, 2013), pp. 30-31

Ahid, Nur, 'Konsep Dan Teori Kurikulum Dalam Dunia Pendidikan', Islamica, 1 (2006), 12-29

Azhari, Muhammad, 'PENINGKATAN MUTU PENDIDIKAN ( Studi Kasus

Pondok Pesantren Ulumul Qur ' an Stabat )', 124-35

Baharun, Hasan, Pengembangan Kurikulum : TEORI DAN PRAKTIK, 2017

Bahri, Syamsul, 'Pengembangan Kurikulum Dasar Dan Tujuannya', Jurnal Ilmiah Islam Futura, 11 (2014), 15 <https://doi.org/10.22373/jiif.v11i1.61>

Daud, Dazmin, and Halim Ahmad, 'Oliva Model in Malaysian Logistics Curriculum: A Conceptual Framework Paper', 2 (2012), 217-28 $<$ https://doi.org/10.5296/ijld.v2i3.1884>

Didiyanto, 'PARADIGMA PENGEMBANGAN KURIKULUM PAI DI Abstrak', Edureligia, 1 (2017)

Fauzi, Ahmad, Hasan Baharun, Akmal Mundiri, and Musolli Manshur, Umar, 'E-Learning in Pesantren: Learning Transformation Based on the Value of Pesantren', Journal of Physics: Conf. Series 1114, 1114 (2018), 1-6 <https://doi.org/10.1088/1742-6596/1114/1/012062>

Hasan Baharun, Syafiqiyah Adhimiy, 'Curriculum Development Throught Creatibe Lesson Plan', Cendikia, 16 (2018), 41-62

Hasan Baharun, Zamroni, Manajemen Mutu Pendidikan: Ikbtiar Dalam Meningkatkan Mutu Pendidikan Madrasah Melalui Pendekatan Balanced Scorecard (Tulungagung: Akademia Pustaka, 2017) 
74 | TADBIR : Jurnal Studi Manajemen Pendidikan, Vol. 3, No. 1, Mei 2019

Hidayati, Wiji, 'Manajemen Kurikulum Pendidikan Agama Islam Dan Budi Pekerti Jenjang SMA Bermuatan Keilmuan Integrasi Interkoneksi', 1 (2016), 195-225

Kaimuddin, 'Implementasi Pendidikan Karakter Dalam Kurikulum 2013', Dinamika Ilmu, $\quad 14 \quad$ (2014), $47-64$ < https://doi.org/10.1061/(ASCE)0733-9410(1991)117>

Khuzaimah, 'Paradigma Pengembangan Kurikulum Pendidikan Agama Islam Di Sekolah (Analisis Berbagai Kritik Terhadap PAI)', Pendidikan, V (2017), $105-18$

Kurniawan, Sugeng, 'KONSEP MANAJEMEN PENDIDIKAN ISLAM PERSPEKTIF AL-QUR' AN DAN AL-HADITS', Nur El-Islam, 2 (2006), 1-34

Mamentu, Meike D, and M Si, 'Manajemen Pendidikan Dan Pengajar Pada Sma Negeri Remboken Kabupaten Minahasa', 3 (2013), 58-66

Mushfi, Muhammad, and El Iq, 'Implementasi Media Pembelajaran Berbasis Teknologi Informasi Dan Komunikasi Dalam', Tarbiyatuna, 3 (2019), $28-38$

Najib, 'Manajemen Masjid Sekolah Sebagai Laboratorium Pendidikan Karakter Konsep Dan Implementasinya' (Yogyakarta: Cava Media, 2015), p. 5

Nasbi, Ibrahim, 'Manajemen Kurikulum':, JURNAL ID AARAH, I (2017), 31830

Nur, Vivit, Arista Putra, and Universitas Gadjah Mada, 'Manajemen Perencanaan Pembelajaran Untuk Kaderisasi Muballigh Di Pondok Pesantren Takwinul Muballlighin Yogyakarta', 3 (2018)

Pidarta, Made, 'Manajemen Pendidikan Indonesia' (jakarta: PT Renika Cipta, 2011), p. 26

Rouf, Muhammad, 'MANAJEMEN KURIKULUM INTEGRATIF 
MADRASAH - PESANTREN', Al-Hikmah Studi Keisaman, 6 (2016), $1-21$

Triyono, Ayon, 'Pradigma Baru Manajemen Sumber Daya Manusia' (jakarta: Oryza, 2012), p. 12

Wahyudi, Dinn, 'MANAJEMEN KURIKULUM DALAM PENDIDIKAN PROFESI GURU (STUDI KASUS DI UNIVERSITAS PENDIDIKAN INDONESIA)', Jurnal Kependidikan, 46 (2016), 25970 